\title{
5. Changing Contours of Corruption in Western Political Thought, c. 1200-1700
}

\section{Bruce Buchan}

While the concept of 'corruption' has played a prominent part in the history of Western political thought, it has rarely excited sustained analysis. Today, corruption is usually used to refer to a particular kind of misdemeanour in public office. In contemporary neo-liberal economic thought, a primary aim of governments is to secure the requirements for a healthy domestic economy underpinned by foreign investment, and among these requirements is the elimination of 'corruption' (see International Monetary Fund, 1997). Corruption here denotes forms of behaviour that threaten to subvert the separation of government and economy, and impose wasteful costs (Dearden, 2003). This technocratic view of corruption is well entrenched in recent literature (Nicholls, et al., 2006; Nye, 2002; Rose-Ackerman, 1999; Shah, 2006). The term itself is most often used today to describe those activities, such as bribery or other private inducements offered to determine public decisions, in which public officials violate rules or laws for the sake of private, usually pecuniary, gain.

One criticism of this approach is that it obscures the normative dimension of the term 'corruption' - that is, it is a term that is defined by a prior conception (or assumption) of an un-corrupted condition, and hence of a particular vision of the boundaries supposed to have prevented the contamination of corruption. As Philp (1997) suggests, identifying political corruption assumes an ideal image of an uncorrupted politics. Rather than a self-evident category of conduct, corruption is a political concept whose parameters are set by an implicit vision of what the political realm actually is. It will be argued in this chapter that the concept of corruption has played an important role in Western political thought in helping to define the nature of politics itself. Over time, however, the conceptual contours of corruption have shifted, as have the ideas of politics with which corruption is entwined. In medieval political thought, corruption was a term used to trace the 'health' of the community to its moral qualities, and especially to the emulation of virtue among its members. A new language of politics began to emerge in parts of Europe in the seventeenth and eighteenth centuries, partly in response to the growing influence of commerce and trade (Hirschman, 1977, pp. 39-40). In this new language, the polity came to be conceived as an artefact of governmental activity premised on the separation of public and private interests. Importantly, this meant that the 'political health' 
of the polity was not held to depend on virtue (or 'political disease' on vice), but on the governmental management of separate but interdependent political, social and especially economic realms (Doyle, 2004, pp. 86-7, 93-4). In tracing this shift, corruption emerges as a very elastic term but an important indicator of the development of early modern European political thought.

\section{The moral physics of corruption}

It is a commonplace of the literature on corruption that modern usage of the term to denote the use of public office for private (pecuniary) gain has substantially changed from ancient Greek and medieval usages. In ancient Greek thought, Euben (1989) maintains, corruption was understood to refer to the process and effects of change, but specifically denoted decay or degeneration. Degeneration could be both physical and moral. In his Ethics, for example, Aristotle (384-322 $\mathrm{BC}$ ) likened moral decay to physical decay by contrasting it with the optimal condition or mean:

[B]oth excessive and insufficient exercise destroy one's strength... whereas the right quantity produces, increases and preserves it. So it is the same with temperance, courage and other virtues. The man who shuns and fears everything and stands up to nothing becomes a coward; the man who is afraid of nothing at all, but marches up to every danger, becomes foolhardy. Similarly the man who indulges in every pleasure and refrains from none becomes licentious...Thus temperance and courage are destroyed by excess and deficiency and preserved by the mean. (Aristotle, 1976 [335-323 BC], II 2, 1104a)

In moral terms, then, virtue denoted a carefully judged mean between excess and deficiency. Thus 'corruption' might refer to the process by which a virtue such as liberality gives way to vices such as prodigality (wastefulness) or illiberality (meanness). Aristotle (1976 [335-323 BC],VII 1, 1145a-b) seems not to have used the term 'corruption' to refer to any particular vice, but to refer to the fact that a virtuous person can be 'corrupted' by vice. Aristotle referred to vices that have come to be associated with corruption as a particular form of action, such as greed or avarice, as vices of licentiousness and prodigality. The licentious, he argues in the Ethics, are especially to blame because they voluntarily surrender to pleasure, while the prodigal are so desirous of making money that they 'take [it] from the wrong sources', and indeed are also licentious in their 'selfindulgence' (1976 [335-323 BC], IV 1, 1120b, 1121b).

In politics, the problem of personal vice is important because the inability (or unwillingness) to make wise and balanced judgments leads people to harbour grievances and form factions (due to envy or malice), and this, Aristotle 
maintained, was the chief cause of constitutional change (1962 [335-323 BC], V, 1302a34). Aristotle's political thought was coloured by the need to preserve the political community by balancing the ever-present tension between the rich and the poor. Rather than opting for a simple ideal type of regime, he appears to have favoured the supreme need to preserve the political community from dissolution, even to the extent of proffering advice to tyrants on how best to preserve their rule (Aristotle, 1962 [335-323 BC], V, 1313a18 - 1315a40). The political 'mean' Aristotle endorsed was a kind of mixed constitution in which democracy, monarchy or aristocracy alone did not prevail, but the finished form or 'polity' borrowed and combined elements of each. Although such a community could be described as imperfect, it had the greatest chance of preservation and longevity, and therefore of staving off the horrors of political dissolution (Aristotle, 1962 [335-323 BC], 1288b). For Aristotle, then, the political problem of corruption was not defined by private misuse of public funds, though he recognised this as a problem, but the larger problem of how to prevent the 'corruption' (understood as the degeneration or dissolution) of the polity itself.

For Cicero (106-43 BC), too, corruption could denote both a moral and a political problem. Among the injustices citizens may commit through fear or desire, he singled out the danger of avarice or the 'desire for money [that] has become unlimited' (infinita cupiditas pecuniae) (1991 [44 BC], 1.8). Among those charged with 'care for the whole body of the republic', it was necessary that virtues (chiefly liberality, beneficence, faithfulness and gentleness) be emulated to prevent the 'corrupting influence' (corruptelam) of money (1991 [44 BC], 2.15). Cicero's concerns here related to the inappropriate uses of money as gifts, presents or bribes (pecuniae) to sway popular opinion, but also included some criticism of the inappropriate use of patronage relations to manipulate judicial decisions by favouratism (gratia). It even encompassed his critique of 'maritime cities' (such as Carthage and Corinth), whose exclusive focus on trade led to luxury, idleness and 'corruption (corruptela) and alteration of character' (Cicero, 1999 [c. 51 BC]). For Cicero, then, corruption could be said to denote a range of moral, legal and political distortions caused by the inordinate love of and misuses of money (avaritia). Yet at all times corruption was a danger that could be circumvented or arrested by the proper cultivation of virtue (Nederman, 1988, p. 5).

For later Christian thinkers such as Saint Augustine (354-430), arresting corruption was a near impossibility, a conclusion to which he seemed 'resigned' (Kaufman, 2009, p. 56). Augustine's pessimism about corruption was coloured by the problem of original sin-the 'corrupt root' of human nature (Saint Augustine, 1998 [413-26 AD], p. 556). A key problem for medieval Christian thinkers was therefore how to reconcile the Ciceronian and Aristotelian emphases 
on human reason and moral judgment with the Christian doctrine of sin. In medieval European thought, forms of pecuniary impropriety such as venality or simony could be denounced not only as moral failures, but also as spiritual failures carrying strong connotations of the sin of avarice (McCall, 1979, pp. 24-6). According to Coleman (1988), the problem of avarice in medieval political thought consisted in the immoderate love of money supplanting the love that human beings should have for God or for each other (p. 624). The solution to the problem of avarice, however, could be framed in distinctly Aristotelian terms, requiring the restoration of the 'right order of things' by the exercise of virtues such as liberality. Consequently, the key to the public, political wellbeing of the community lay in the exercise of the appropriate virtues by its members. Historians have argued that this conception of the direct relationship between virtue and politics precluded a conception of public office or 'politics' as a distinct field of activity characterised by its own norms of disinterested and 'rational' conduct (see Génaux, 2002, pp. 107-8; Swart, 2002, pp. 96-7; Waquet, 1991, pp. 10-14). Medieval understandings of politics were often expressed in terms of an organic unity of the entire community (Harvey, 1999, pp. 85-93; Kantorowicz, 1957, p. 199; Von Gierke, 1958 [1900], p. 8). This image was often expressed through the analogue of the 'body politic' — an image that could be used to reinforce hierarchical notions of the supremacy of the monarch ('the head') or to emphasise the interdependence of each part in the whole (Nederman, 2000b, 2004, p. 61). As John of Salisbury (c. 1115-80) described it, the political community could be thought of as consisting of several connected members, just like a human body. Most importantly, John's body politic made special mention of the treasury and the need to regulate it: 'Treasurers and record-keepers...resemble the shape of the stomach and intestines; these, if they accumulate with great avidity and tenaciously preserve their accumulation, engender innumerable and incurable diseases so that their infection threatens to ruin the whole body' (John of Salisbury, 1990 [c. 1159], p. 67).

Importantly, John identified finance as crucial (for nourishment of the body) but dangerous if not properly regulated (causing disease and infection in the body). ${ }^{1}$ While John thought it expedient for the ruler to be wealthy, he argued that the ruler must count their wealth as the people's (p. 40). John also stipulated that no-one 'who governs is to accept a present or gift, except of food or drink', although they ought not to refuse gifts entirely but to exercise moderation (p. 97). His reasoning here was that it would require 'an inhuman strength to accept from no one; but to accept indiscriminately is most vile; and for all things,

1 John's use of the 'body politic' metaphor (along with Christine de Pizan's later use of a similar metaphor) here reinforced the importance of wealth creation to the health of the polity, and the need to differentiate appropriate wealth creation from the potentially corrupting influence wealth might have on the exercise of public authority (Pizan 1994 [1404-07], pp. 103-4). 
most avaricious' (ibid.). He was clear here also that acceptable gifts included 'perishable', consumable items, and anything in the way of money or property must not 'take on the character of remuneration' (ibid.).

These concerns certainly pertain to what we would consider today as 'corruption', but as a churchman John was also concerned with the spiritual dimension. In this vein, he spoke of corruption in the rubric of 'avarice', indicating both a sin against God and a failure of moral judgment. Above all, corruption was linked to the cardinal sin of pride, which he described as the 'root of all the evils that feed mortality', a 'poisonous vice' or 'virus of mortification' capable of 'infecting the vital organs' (p. 17). Those infected with pride turned away from God and towards transient and perishable desire, sensuality, money or earthly powerin short, all 'things...corruptible and false' (corruptibilium et corrumpentium) ( $\mathrm{p}$. 18). Hence, the avaricious 'love of money' that led to corruption was opposed to the godly 'love of incorruptibility' (incorruptionis) (p. 101). ${ }^{2}$ In this sense, corruption could denote not simply a particular act or abuse of public office, but a whole process of spiritual, moral and bodily decay (Binski, 1996, pp. 134-8). This image of corruption, Gonzalez (2005) contends, also had strong theological overtones in medieval Roman Catholic doctrine. Corruption, so it was thought, was the fate of all human beings: the physical decay of the body was the necessary step to the resurrection of the soul and, at the last judgment, to the triumph over corruption when the 'dead shall be raised incorruptible'. Tales of the apparent lack of physical corruption in the remains of the saints was interpreted as a sign of their holiness, of their having triumphed over death and corruption and that their 'spirits live with God' (Saint Augustine, 1998 [413-26 $\mathrm{AD}]$, p. 1135).

The political problem of sin or vice in the 'body politic' was that if it took hold in one segment of the 'body politic' it may cause the 'disease' to spread, disrupting the relationships between its various parts. ${ }^{3}$ While the corruption of the individual's body was something to be embraced, Génaux (2002, pp. 115-16) points out that the corruption of the body politic was something to be avoided. If it were to be avoided, some way had to be envisaged to prevent potential sources of corruption in the body politic from infecting all the other members. Marsilius of Padua (1275-1342) marshalled an Aristotelian scheme of 'temperate' and 'intemperate' polities in order to argue that 'bad' polities were those in which public authority was under the sway of those who were not motivated by or able to protect the common good. He spoke of regimes as either 'well-tempered' or 'flawed' (2005 [1324], I.vii.2). The difference between them

2 John of Salisbury (1909, §587c, p. 367)

3 The problem was further complicated by the doctrine of the monarch's two bodies: the individual person who passes away, and the person as embodiment of the state or dignitas that lives on beyond the individual's death (Kantorowicz, 1957, pp. 30-40, 407). 
consisted in how well distinct and identifiable boundaries between spheres of responsibility were maintained, and especially the boundaries between secular and religious authorities (II.ii.2). Possibly betraying his medical schooling, Marsilius tends to phrase his arguments in medical terms. Hence, for example, civil strife is 'diagnosed' (dignoscitur) as a 'contagious' (contagiosa) 'illness' or 'indisposition of a civil regime' (civilis regiminis disposicio) (I.i.3).

When his attention shifts to analysing the specific problems presented by the unwarranted claims of the church over secular rulers, there is a detectable shift in Marsilius's tone. One of his chief concerns was that church authorities were especially prone to avarice, decadence and simony, and other 'improprieties' in distributing offices for a price to the ignorant, the criminal, children, unidentified persons, and those who are either detestable or manifest idiots' (II.ii.6). In this vein, Marsilius warned of the 'civil inconvenience' caused by 'corrupt' (sacerdos perversus) priests who can 'corrupt' (corrumpere) the morals of their flock (2005 [1324], II.xvii.12). Marsilius considers this a far worse danger than that of a 'corrupt prince' (perversus princeps) whose corruption dies with him, because priestly corruption results in 'eternal death' for those corrupted (XIII.xvii.15). In addition, corrupt church officials endangered the mystical unity of the faithful because they 'infected and...corrupted the entire mystical body of Christ' (infecerunt...corruperunt) (II.xxiv.2). Yet the problem of church corruption was not merely spiritual. Corrupted church officials, Marsilius argued, were likely to appoint other avaricious and criminal (criminosum) officials and 'men...of corrupt mind' (corruptos), whose perversity would expose not only the church but also 'all realms and all polities...to the danger of dissolution' (II.xxi.12). A key problem was that papal claims to supremacy (or 'plenitude of power') had been used by the church to exempt it from secular oversight. In this way, the corrupted church had 'corrupted' (corruptis) the morals of the faithful leading to civil strife, vice, error and dissolution of morals and good order (II. xxvi.19).

Marsilius's references to 'corruption' have a number of interesting features. First and most obviously, corruption was understood (in line with classical and Christian teachings) in terms of moral and physical degeneration; however, he used the term alongside others such as 'perversion' and 'criminality' that clearly denoted deliberate wrongdoing, and 'infection', which likened corruption to a disease with specific causes and effects, requiring specific treatments. Corruption was linked above all with his denunciations of the church, its overinflated political claims and especially its effects on the political realm. The corruption of the church was manifested in its erroneous and self-interested teachings, in rampant sale of offices or the rendering of spiritual services in exchange for money. Importantly, those described as 'corrupt' were those least 
fitted for, or compromised in, exercising their authority. Above all, however, corruption represented a grave political problem in that it was closely related to civil disturbance, strife and potential political dissolution.

This representation of the problem of corruption had important implications. It implied that there were different and distinct spheres of secular and spiritual authority, and that the transgression of the boundaries between them represented a kind of corruption. Thus, corruption represented not simply a form of moral decay or disease, but a disruption of the equilibrium of the wellordered, temperate state. Marsilius's references to corruption further implied that corruption consisted in a particular kind of transgression-namely, the control of public authority by inappropriate persons. Such misrule is to be avoided because it threatens to subvert the peace and good order of the state, undermining the advantages (commodis) that flow from it, including the private pursuit of wealth and sufficiency (Nederman, 2003, pp. 402-3, 4067). While medieval thought had often considered moneymaking for its own sake to be avaricious and thereby 'corrupt' or 'corrupting', Nederman (2000a, p. 2) reminds us that medieval thinkers were well engaged with analyses of private and national wealth 'as a pursuit worthy in itself' (p. 2). More positive attitudes towards moneymaking began to develop in Europe in the wake of widespread economic changes and the development of international trade throughout the fourteenth and fifteenth centuries. Throughout the Renaissance period (c. 1400-1650), lavish consumption was employed as a demonstration of status or princely power (Jardine, 1996, pp. 327-8). Nonetheless, important doubts about the moral effects of moneymaking, and of what could be termed a 'market economy', persisted (J. R. Hale, 1993, pp. 384-5; Schama, 1987, p. 371). Importantly, early modern usage of the term 'corruption' denoted a problem that had implications not simply for the individual but also for the wider community and polity.

\section{Machiavelli's two dimensions of corruption}

Niccolò Machiavelli's (1469-1527) use of the term 'corruption' encompassed a range of distinct phenomena related by the fact that their appearance denoted degeneracy in the public, political life of the republic. Corruption could mean widespread decadence or indolence, a loss of good order and discipline among the citizens, a loss of military prowess, the predominance of faction or private interests over the common interest or the preponderance of the wealthy and powerful over the commonality. The first three and the last two phenomena are closely related, and I propose to discuss them as two dimensions of Machiavelli's understanding of corruption, first as loss of discipline or virtù and, second, as a preponderance of private interests over the public interest. 
According to Pocock (1975), Machiavelli decisively shaped the civic-humanist ideal of the active citizen engaging in public deliberations within the polis by sensing that the framework of institutions that supported-indeed, enabledsuch a concept of citizenship to occur had collapsed. The political world of the modern polis, the Italian republic of the fifteenth century (such as Florence or Venice), existed in a world of flux, indeterminacy and uncertain fortune (fortuna). In this environment, the idea of the active citizen needed a new foundation, a new set of orders (ordini) that made the pursuit of virtue (virtù) comprehensible. In response to this perceived need, Machiavelli provided a radically new account of the possibilities for virtue in a world where its opposite - corruption (corruzione) —was an ever-present possibility. Pocock (1975) contends that Machiavelli accomplished this new account by tying the mercurial concept of virtù, with its connotations of both individual excellence in judgment and decisiveness in action, to a notion of political virtue consisting in a collective pursuit of the health of the republic through commitment to the general good. Most importantly, he identified a citizen's militia as the vital mechanism by which individual citizens could receive training in the virtues of war (discipline, courage, fortitude) and the virtues of political stability (loyalty, obedience and love of homeland).

Republics, Machiavelli argued, could not avoid the challenges of war and conquest. All republics are brought by 'necessity' (necessità) to defend themselves from outside aggression and are moved by the constant 'motion' that means that things 'cannot stay steady', 'must either rise or fall' and so must be prepared to conquer (1996 [c. 1517], I.vi.22-3). Machiavelli's concept of corruption emerges in light of his analysis of the fate of republics governed by a 'mixed constitution', which was not solely produced by constitutional design, but by political contest between the forces of monarchy, aristocracy and populace (I.iii.15). The maintenance of a balance between these forces, however, is a very difficult operation, requiring the active management of public 'manners and customs' and the inculcation of virtù. It is in this sense that he spoke of the difficulty of re-establishing a mixed constitution in a republic that has become corrupted (corrotto). Here corruption is used in the context of describing the falling away of regimes from a former glory. Machiavelli's analysis here imbibes the Polybian imagery of a cycle of greatness and decline through which states pass. Conquests and imperial greatness are won by virtue; decline is brought about by the decadence that greatness facilitates, leading to an indulgence in excess and luxury or a loss of discipline among the citizens. Crucially, the danger of corruption is explicitly associated not only with those who hold public office, but also with the entire populace and the institutions of the republic (I.xvii.47). For Machiavelli, then, as Rahe (2009) has suggested, corruption and virtue were 
treated as political phenomena indicating 'the absence or presence of clientitial relations' and the either virtuous or corrupted behaviours associated with them (p. 48).

Virtue was closely associated with military service and training, and the association was emphasised in his The art of war. Here, Machiavelli contends that the moderns (especially the Italians, and to a lesser degree the French and Spaniards) had fallen away from their former virtues, and instead of continuing honest and wholesome had become dishonest and corrupt (1965 [1521], p. 10). The idea of corruption as a falling away from earlier virtue was a favourite theme in Machiavelli's thought. It is exemplified in a speech he puts into the mouth of an unnamed speaker who voiced the concerns of the people of Florence in 1372 in his Florentine histories. Motivated by 'love of their country' to complain to their government (Signory) through their unnamed mouthpiece, the people of Florence bewailed the 'universal corruption' that had 'infected' all Italian cities, including their own (Machiavelli, 1906 [1532], p. 167). This corruption was marked by incessant factional strife, feuds, faithlessness, avarice, luxury, indolence, deception and a general shunning of virtue in favour of whatever vice proves serviceable. What emerges from this speech is an understanding of corruption consisting of both the general phenomenon of moral decline in Italian cities and the variety of specific behaviours in which this decline is manifested and by which it has come to pass: 'truly in the cities of Italy there is to be found gathered together all that can either corrupt, or be corrupted' (p. 168). Corruption, for example, could denote greed or factionalism or indolence; but these behaviours were also corrupting, causing a weakening of public institutions and an erosion or degradation of public spirit, discipline or fortitude. In both the Florentine histories and The art of war, Machiavelli harped on the theme that contemporary Italian citizens, and especially their rulers, had renounced lives of discipline, self-sacrifice, devotion to public duty, hardship and exertion, and that such was the corruption of the age, none seemed able to deviate in the slightest from the now common indolence and to aspire to virtù.

Virtù has often been represented as the sum of a prince's 'manly' cunning and ruthlessness in the constant struggle to master fortuna; however, a fuller appreciation of virtù would have to include other skills, such as the emulation and inculcation of the qualities of a well-disciplined militia: order, endurance, fortitude and courage (Machiavelli, 1996 [c. 1517], II.ixx.172-3). For Machiavelli, then, one dimension of corruption centred on the loss of virtù; the other dimension connected the loss of virtù to a more modern conception of a separation of public and private interests. Towards the end of Book I of The discourses, Machiavelli speaks of states that are 'corrupt' (corroto) in the rather unusual context of not surrendering private wealth to the public account (I.lv.109-13). At first glance, this would appear to be a simple reflection on 
public honesty, but it also touches on a conception of the due relation between private and public realms with specific reference to finance, taxation and the influence of the wealthy.

Machiavelli developed his view in reflecting on the Germans, who, he believed, were 'honest' and displayed 'probity' by their voluntary commitment to paying their taxes and preventing any of their citizens from becoming 'gentlemen'. Gentlemen, it appears, were the chief promoters of all corruption because they lived in splendour, idleness and indulgence, possessed greater wealth and were especially dangerous when they maintained castles and retainers. Here we have a notion of 'corruption' that has two dimensions: one denoting a loss of virtù, the other suggesting a blurring of public and private interests weakening the 'political equality' on which the republic rested. Where corruption occurs in any part of the citizen body, it may be corrected if the entire republic has not already become too 'corrupt'. Though Machiavelli did not explicitly evoke the image of the 'body politic', he did make the analogy between the 'corruption' of the republic and physical illness, both of which will prove fatal 'unless something intervenes' (Machiavelli, 1996 [c. 1517], III.i.397-8). The autonomy of politics, then, consisted in the contest between political actors for 'glory' or supremacy within the city. The second dimension of corruption threatened the collapse of this autonomy when the public interest was supplanted by the ruler's private interests (Fontana, 2003, pp. 106-8).

It is at this point that the sting in the tail of Machiavelli's analysis of corruption, virtue and empire emerges. By means of virtù, leaders emerge in the quest for empire, and by means of their and the citizens' virtue republics acquire empire; however, while the liberty that is born of civil conflict in the republic delivers these great benefits, the empire that it also helps to win tempts leaders and citizens to excess and decadence, and thus to corruption. Relying on Machiavelli's account of the demise of Rome to the tyranny of Julius Caesar, Mansfield (1996) argues that corruption is 'the necessary consequence of republican virtue and, in a prince, the necessity of his nature' (p. xxxii). It is certainly true that Machiavelli traces a line that may lead from virtù to corruption (1996 [c. 1517], III.xxiv.269-70), but this trajectory does not seem to be inevitable. As Machiavelli's unnamed speaker put it in his Florentine histories, though 'great be her corruption', Florence may with 'better methods' of government and renewed purpose be 'rid' of the 'distemper that infects' the republic (Machiavelli, 1906 [1532], p. 172).

For Machiavelli, then, the problem of corruption was not simply a personal moral failing, but a political problem with systemic implications. But it would not be entirely correct to picture Machiavelli's as a functionalist analysis of corruption. As Germino (1972) has pointed out, central to Machiavelli's analysis was the idea of political humours (umori) corresponding with the appetitive 
motivations of competing social groupings (most notably, 'humouric struggle' or dynamic tension between the plebians and nobility that helped make Rome great) (pp. 67-8). As this language implies, Machiavelli sometimes spoke metaphorically of the polity as being prone to humouric imbalances or illnesses requiring medical treatment, but he tended not to use the language of the body political in any extended sense. While it would be fair to say that only part of Machiavelli's concerns about corruption related specifically to money and wealth, Pocock (1975) argues that Western political thinkers in the seventeenth century did come to share a concern over the possibilities for enhanced corruption (pp. 466-7). Their concern often related to the rise of 'new' forms of financial wealth undermining the tangible, solid and intergenerational stake in the commonwealth that landownership was thought to provide. In this new environment, Pocock argues, fortuna was gradually replaced with corruption as the chief danger to virtue, and the implications of this shift are most apparent in British political thought (p. 402).

\section{Commerce and the rhetoric of corruption}

While a range of European political thinkers in the early modern period thought commerce extended the possibilities for corruption, the gradually narrowing definition of corruption in this period also suggests other conceptual shifts were taking place. The changing contours of corruption can be correlated, for example, with the decline of the metaphor of the 'body politic', and the identification of new dynamics of political development focused on ensuring the financial viability and military security of sovereign states, and a political balance between newly emerging social classes. Momentum for this kind of conceptual shift built slowly throughout the late Elizabethan and Stuart reigns, during which rises in inflation and the inability of the state to levy and raise efficient taxation put pressure on state functionaries to pursue private gain through public office. This kind of concern was voiced by John Ponet (1556), for whom the good ruler seeks 'the wealthe of those he ruleth', whereas the 'evil' ruler 'spoyleth the people of their goodes' by 'making his ministers to take' them 'under the name of loanes, benevolences, contribuciones, and suche like gaye paynted wordes' (Chapter 6).

For some, the problem lay in the acquisitiveness and rapacity of human nature. Here corruption threatened when self-interest or affections overbore reason and good judgment, which was a perpetual problem because all humans were 'subiecte to affectes and all corruption' by our 'corrupte iudgements' or 'corrupte affection' (Starkey, 1973 [1540], pp. 17, 27, 39). Nonetheless, it did not necessarily follow that corruption was uniformly identified simply with the undue influence of private interests in public life. Throughout the Renaissance, patronage 
remained a central feature of political life at royal courts across Europe. Harding (1981) suggests that the practitioners and beneficiaries of the often subtle game of seeking and receiving patronage may have been just as keen to protect it from corruption as its critics were to construe it as corruption (p. 63). As Peck (1990) observes, contested rhetorical denunciations of patronage as corruption resulted in the concept of corruption becoming a crucial ideological weapon in parliamentary efforts to control royal revenues in seventeenth-century England (pp. 186, 203). According to Asch (1999), however, the emergence of corruption as a more clearly defined crime in European thought was a result of efforts to find a less damaging, indeed 'consensual' way to bring the sovereign to book (p. 105). The language of the 'body politic', in other words, left few options for rethinking the place of the sovereign in relation to the other members of the 'body'. ${ }^{4}$ Recasting that relationship required a language able to separate the monarch's private person more clearly from their persona as embodiment of the 'body politic'. A narrower conception of corruption was an important tool in that quest. Adding impetus to the narrowing of the concept of corruption was the development of a new conception of the polity in which political stability was gradually divorced from citizen virtue, and tied to the effective management of the conditions favouring the development of a market economy.

The progress of these conceptual shifts can be gauged in a variety of texts from the Elizabethan and Stuart periods. Edmund Dudley's (1462-1510) Tree of commonwealth, for instance, was based on an alternative organic metaphorthat of the state as a tree whose 'roots' (concord, justice and peace) needed to be secured and were capable of producing 'fruits' (tranquillity, prosperity and dignity). Among the chief dangers to the 'health' of the 'tree', he argued, were simony, the '[b]eastly appetite' of covetousness and the 'venemeous core' of the fruit of prosperity, 'vaine delectacion', which 'alienate[s]...the mynd of man from god and good vertues' (Dudley, 1948 [1509], pp. 25, 26, 77). For Dudley, then, undue pecuniary interests were not spoken of as corruption, but were referred to under the conventional rubric of particular charges (such as simony) or a lack of virtue. Corruption, where it was referred to, denoted decay, 'disease' or perishability, brought on by vices such as 'vain delectation' whereby a person bestows his love 'only and intierly in corruptible and transytorie vanyitie' (pp. $94,79)$. The association of undue pecuniary interest in public office with the lack of virtue, and of corruption as a loss or decay of virtue, remained in place in Britain in the sixteenth century. In a case of electoral bribery in 1571, for instance, Thomas Long was charged not with corruption, but with a 'lewd and

4 McLaren (1996, pp. 248-252) argues that the succession of Elizabeth I as the Protestant saviour in England raised other concerns related to the effects of a female 'head' of state. The inversion of traditional gender roles could be seen, as Knox certainly did, as corruption (Knox 1878 [1558], p. 48). Nonetheless, early modern political thought also provided avenues for representing politically influential women as virtuous opponents of corruption (Hicks, 2005). 
slanderous' act (in Tanner, 1951, p. 527), while the danger of treason could be described in an official proclamation of 1601 as consisting in 'how many hearts it hath corrupted' (in Kinney, 1990, p. 326).

Nonetheless, the contours of the language of virtue and politics, pecuniary interest and corruption were changing throughout this period. In 1581, for instance, a treatise by 'W. S.' (1954 [1581]) on the impact of inflation on English society was couched in the conventional garb of the 'goode virtues' that show the '[i]mage of god in man' (p. 14). But while virtue clothed the rhetoric, the analysis suggested a new dynamic art of good government consisting in the regulation of exchange and coinage as a means of mediating between the interrelated but independent sectors of society engaged in separate economic pursuits. Nonetheless, older notions of the organic unity of the 'body politic' still made sense, as the preamble to the Lay Subsidy Act of 1601 shows (in Tanner, 1951, p. 612). Here the parliament could still refer to themselves as her majesty's 'faithful and obedient subjects' constituting 'one Body Politic' in which 'your Highness is the head and we the members'. ${ }^{5}$

Just as the image of the political community was shifting, the rhetorical appeal of corruption was also characterised by wide contours of meaning. As Noonan (1984) suggests, corruption still imbibed 'images of evil' that 'designate what destroys wholesomeness', but also pointed to specific misdemeanours such as the 'corruption of justice by bribery' (p. 322). For instance, in the impeachment in 1621 of the Lord Chancellor, Sir Francis Bacon, corruption was linked with bribery in what appears to be a consistently modern and narrow implication of the term. Interestingly, Sir Francis attempted to extenuate his guilt on the grounds that he 'was never noted for an avaricious man' and that the charges (all 23 of them) were mostly old misdemeanours that had not been continued, 'whereas those that have an habit of corruption do commonly wax worse and worse' (in Tanner, 1951, pp. 332-3). Bacon's linking of corruption with avarice and the danger of its 'infectious' spread was no more than a very distant echo of the older language of corruption as a loss of virtue.

The same echoes could be heard in the contest between King Charles I and his parliament in the 1640s, in which parliament complained of the 'corrupt and illaffected party' advising the King who had managed to 'corrupt divers' bishops and to maintain 'pressures and corruptions wherewith your people have been grieved' (in Hughes, 1980, pp. 76-7). Corruption here meant both self-interested and extortionate financial measures and the deviation of the bishops from God's authentic word (as factions in parliament saw it). The King responded by

5 Here I leave aside the ambiguities associated with the legal doctrine of the 'body politic' defined by Lord Coke in Calvin's case in 1608, by which the monarch's private (mortal) person was separated from the public (immortal) person of the state (Thomas, 1986 [1836), p. 59). 
buttressing his own claim to a divine sanction to rule by rejecting parliament's charge of 'corruptions (as you style them) in religion' (Hughes, 1980, p. 79). This exchange highlighted a connotation of the term 'corruption' derived from Aristotelian physics, in which corruption conveyed a deviation or perversion from some original state or condition. Some eight years later, in 1649, as he was about to pay for defeat in the civil war (1642-49) with his life, Charles reflected that divine sanction or no, only in resurrection could any human, even a king, triumph over corruption. Standing on the scaffold in Whitehall, he said to Dr Juxon: 'I go from a corruptible, to an incorruptible Crown; where no disturbance can be, no disturbance in the World' (King Charls his Speech made upon the Scaffold, 1649). The contours of corruption continued to shift as the very image of the 'body politic' itself was transformed by the trauma of the decapitation of the King as 'head' of the English 'body politic', and the attenuated rulership in his wake of the infamous 'Rump' Parliament (Jenner, 2002, pp. 96-102).

As the new political settlement in England was forged in the later half of the seventeenth century, corruption appeared in the efforts that political writers were making to define the role of commerce and its relationship to the distribution of power. For James Harrington (1611-77), for instance, a healthy commonwealth appears to have been one that managed to unite 'authority' or the proper ordering of laws and internal institutions and 'empire' or the control of one's enemies through popular participation in, but gentlemanly leadership of, the militia. He referred to this as 'the plastic art of government' and he suggested that 'interweaving the militia' within the commonwealth was akin to the human skeleton; it was the foundation of 'proportion or symmetry' in both body and polity (Harrington, 1977 [1656], pp. 161-70, 268-70, 299, 303, 312). Corruption referred to the process of change in both political institutions and public manners that follows from alterations to the balance between the forces of property in the republic. While stolid landownership buttressed the pursuit of virtue, Harrington and those who followed him later in the century and into the next worried about the effects of flighty and intangible commercial capital and the potential it created for the 'corruption' of the commonwealth by funding the arbitrary rule of the Crown. Nonetheless, some have claimed that Harrington's account of corruption was 'value-neutral' insofar as he argued that corruption simply meant 'change' in the political balance of forces (Barnouw, 1986, p. 63). Corruption of popular government may therefore lead to tyranny, but the corruption of oligarchical or monarchical government may lead to popular government. Corruption did not necessarily lead to chaos and decay. Nonetheless, a popular commonwealth, Harrington argued, was to be preferred because it 'bringeth the government from a more private unto a more public interest', whereas in oligarchies and monarchies, private interests (such as luxury) prevail (1977 [1656], p. 202). 
An even narrower conception of political corruption can be seen in Harrington's near contemporary Thomas Hobbes (1588-1679), who was less concerned with the conditions for popular government and, indeed, considered it an anathema (Blau, 2009, p. 612). By conceptualising political legitimacy in terms of a contractual bargain between self-interested individuals seeking protection of life and property, Hobbes's thought played a pivotal role in the post-medieval rejection of the Aristotelian framework in Western political thought. Nonetheless, Hobbes's 'modernity' was still coloured by a striking use of the analogy of the body politic in his analysis of the various 'infirmities' and 'diseases' to which a commonwealth may be exposed (Hobbes, 1996 [1651], pp. 221-30). He did not, however, refer to the corruption of the body politic itself, and thus tended to use the term corruption in ways much closer to modern usage (Blau, 2009, p. 601). This is exemplified for instance in his frequent denunciation of the use of bribes to 'buy' judicial opinion or the corruption of 'counsellors' who have been 'bribed by their own interest' (Hobbes, 1996 [1651], p. 178). ${ }^{6}$ Hence, in Chapter 26 of Leviathan he discusses the role and characteristics needed of judges, and speaks of the necessity that their judgments not be corrupted by reward ( $p$. 195). For Hobbes, 'all Lawes dependeth on the Authority Soveraign' and the 'interpreters' (judges) appointed by the sovereign to apply them honestly and in line with their '[i]ntendment, or Meaning' (p. 190). Consequently, he warned of the danger of '[f]alse judgement' procured by 'corruption' of judges or witnesses (pp. 192, 212). For Hobbes, then, corruption in cases of judicial application of the law was tantamount to the vicious subversion of sovereign power, but could also refer to what Blau (2009) calls 'cognitive corruption' or the distortion of judgment by money, affection or misconstrued self-interest, all of which also subvert sovereign authority (pp. 608-12).

For a republican like Algernon Sidney (1622-83), however, the problem of corruption could not be entirely isolated from the virtue (or vice) of the sovereign. In the Court maxims, for instance, he posed the problem in terms of a dynamic relationship between the ruler(s), the law and the virtue of those who administer the law:

[F]aults in the law introduce all manners of corruption into the administration of it. They who corrupted the law for corrupt ends will certainly make a corrupt use of its corruption. The effect of this is that the king does what he pleases, and the courtiers and lawyers get what they please...if there be a great defect in the law, it leaves an easy entrance for corruption in the administration...Again, if there be corruption in

6 Thomas Floyd described judges as the 'Phisicions of the Commonwealth' who dispense the various cures to social and political ills, and who must not be 'corruptible with giftes' (1600, pp. 86-7). 
him or them who administer the law, he or they will corrupt the laws, as the depraved will darkens and corrupts the understanding. (Sidney, 1996 [c. 1665], pp. 131-3)

Sidney's language here is redolent of the ancient Greek notion of corruption as degeneration and decay, overlaid with medical connotations of disease and mortality. Indeed, the imagery becomes more explicit when he continued that corruption was a 'plague' that 'if suffered to continue' would render 'the body that was strong, healthy, and beautiful'

a carcass full of ulcers and pacrid sores. This in physics is called kaka

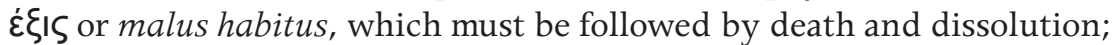

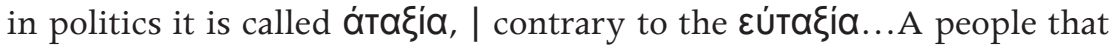
falls into it is in the lowest degree of misery. All order is overthrown. (p. 133)

In the later Discourses, and in response to Filmer's notorious defence of monarchical rule, Sidney considered the chief danger of corruption lay in the sovereign becoming corrupt and corrupting the rest of the community (Sidney, 1990 [c. 1682], pp. 51, 135, 184-5, 229, 252). While his earlier imagery of corruption employed the biological metaphors of disease and decay, his Discourses coupled these metaphors with a strong focus on corruption as a problem of private interests dominating the public administration of the law (pp. 212-13); however, the more perceptive political theorists of the period noted that the development of commerce was transforming the nature of government and society. As they sought to make sense of these transformations, they struggled also to adapt the received language of political discourse to new realities, and the constantly changing contours of corruption were often accompanied by echoes of older organic metaphors of the 'body politic'.

\section{Conclusion}

The prospect of commerce and trade as new and influential political forces bedevilled late-seventeenth-century British political thought, in which one can detect expansive understandings of corruption alongside narrower modern understandings. In the recurrent debates between 'court' and 'country' ideologies throughout the eighteenth century, 'country' partisans might employ the rhetoric of corruption to cover a multitude of sins, ranging from threats to civic virtue from speculative capital and the encroachment of court patronage onto parliamentary independence to simple electoral maladministration (Dickinson, 1977, pp. 10218). As Brewer (1989) has also noted, the rhetorical appeal of corruption lay in its service as an indictment of the current administration, rather than in any genuine determination to achieve wholesale moral reform (p. 74). 
The charge of corruption was slowly detached from claims of moral decay and increasingly associated with specific kinds of misdemeanour in the exercise of public office. Though few went as far as Bernard Mandeville (1670-1733) in endorsing the beneficial effects of the 'slipp'rey...Perquisite' in public office, Mandeville expressed a more popular trend in dismissing the 'body politic' metaphor as 'very low' (1970 [1724], pp. 66, 72-3, 135). As even his strongest critic, Daniel Defoe (1660-1731), recognised, the development of Britain's market economy was transforming the nature of government. This would require new boundaries insulating trade and commerce against undue government interference, but also preventing unscrupulous traders from attempting to 'corrupt and procure' political power (Defoe, 1979 [1701], p. 258). Throughout the eighteenth century, free trade and good government were interpreted by European writers as distinctively European accomplishments, in contrast with the corruption, decadence and luxury of eastern societies (Whelan, 2009, p. 17; Woodfine, 2004, p. 178). Indeed, William Temple (1628-99) had previously recommended the Dutch system of government because it exempted none from the laws, it generally promoted the ablest governors and ensured that 'no great Riches...enter by Publique Payements into Private purses...to feed the prodigal Expenses of vain, extravagant, and luxurious Men' (Temple, 1932 [1690], p. 80). Rather all 'Publique Monies' were 'applied to the Safety, Greatness, or Honour of the State' in which the '[m]agistrates themselves bear an equal share in all the Burthens, they impose' (p. 80).

What writers like Defoe and Mandeville were grasping towards in very different ways were new conceptions of the polity premised on the extension of commerce and trade. Though these 'new' conceptions did not necessarily 'replace' older metaphors of the body politic, they made the application of older metaphors seem increasingly anachronistic (D. Hale, 1973, p. 70). In the terms of the 'new' language of political thought, the stability of the polity came to be seen as an artefact of governmental design decoupled from citizen virtue. As a consequence, the stable polity came to be defined in terms of meeting the requirements for a flourishing market and solvent state. Such definitions conveyed an image of a polity freed from the moral physics of decay. Polities might be well or badly designed, they may be prone to tyranny, popular disorder or poverty, but their very existence was no longer held to depend quite so much on the people's or their sovereign's emulation of virtue. In this context, corruption gradually came to be seen as a more specific problem in the execution of public authority, and its conceptual contours began to coincide more closely with the boundaries that separated private interests from public office. 
Corruption: Expanding the focus

\section{Acknowledgements}

This chapter is based on research supported by the Australian Research Council and Griffith University. It was originally presented in a 2004 seminar at Griffith's School of Humanities and the author would like to thank all those who participated. Thanks are also due to Mark Philp and Cary Nederman for their comments on earlier drafts and, as always, to Kathryn Seymour.

\section{References}

Aristotle (1976 [335-323 BC]). The ethics of Aristotle: The nicomachean ethics (J A K Thomson. Trans). London: Penguin.

Aristotle (1962 [335-323 BC]). The politics. (T. A. Sinclair. Trans). London: Penguin.

Asch, Ronald G. (1999). Corruption and punishment? The rise and fall of Mattäus Enzlin (1556-1613), lawyer and favourite. In J. H. Elliott \& L. W. B. Brockliss (Eds), The world of the favourite (pp. 6-111). New Haven: Yale University Press.

Barnouw, J. (1986). American independence: revolution of the Republican ideal; a response to Pocock's construction of 'the Atlantic republican tradition'. In P. J. Korshin (Ed.), The American revolution and eighteenth-century culture (pp. 31-73). New York: AMS Press.

Binski, Paul. (1996). Medieval death: ritual and representation. Ithaca: Cornell University Press.

Blau, Adrian. (2009). Hobbes on corruption. History of Political Thought, 30(4), 596-616.

Brewer, John. (1989). The sinews of power: war, money and the English state, 1688-1783. New York: Alfred A. Knopf.

Cicero, Marcus Tullius. (1991 [44 BC]). On duties (M. T. Griffin \& E. M. Atkins, Trans). Cambridge: Cambridge University Press.

Cicero, Marcus Tullius. (1999 [c. 51 BC]). On the commonwealth and on the laws (J. E. G. Zetzel, Trans.). Cambridge: Cambridge University Press.

Coleman, Janet. (1988). Property and poverty. In J. H. Burns (Ed.), The Cambridge history of medieval political thought c. 350-1450 (pp. 107-648). Cambridge: Cambridge University Press. 
Dearden, Stephen J. H. (2003). The challenge to corruption and the international business environment. In J. B. Kidd \& F.-J. Richter (Eds), Corruption and governance in Asia (pp. 27-42). Houndmills: Palgrave.

Defoe, Daniel. (1979 [1701]). The freeholder's plea. In L. A. Curtis (Ed.), The versatile Defoe (pp. 151-258). London: George Prior.

Dickinson, H. T. (1977). Liberty and property: political ideology in eighteenthcentury Britain. London: Methuen.

Doyle, William. (2004). Changing notions of public corruption, c. 1770 - c. 1850. In Emmanuel Kreike \& William Chester Jordan (Eds), Corrupt histories (pp. 83-95). New York: University of Rochester Press.

Dudley, Edmund. (1948 [1509]). The tree of commonwealth. D. M. Brodie (Ed.). Cambridge: Cambridge University Press.

Euben, J. Peter. (1989). Corruption. In Terence Ball, James Farr \& R. L. Hanson (Eds), Political innovation and conceptual change (pp. 220-46). Cambridge: Cambridge University Press.

Floyd, Thomas. (1600). The picture of a perfit common wealth, describing as well the offices of princes and inferior magistrates over their subiects. London: Simon Stafford (British Library 873b41).

Fontana, Benedetto. (2003). Sallust and the politics of Machiavelli. History of Political Thought, 24(1), 86-108.

Génaux, Maryvonne. (2002). Early modern corruption in English and French fields of vision. In Arnold J. Heidenheimer \& Michael Johnston (Eds), Political corruption: concepts and contexts (3rd edn, pp. 107-22). New Brunswick: Transaction Publishers.

Germino, Dante. (1972). Machiavelli's thoughts on the psyche and society. In Anthony Parel (Ed.), The political calculus; essays on Machiavelli's philosophy (pp. 69-82). Toronto: University of Toronto Press.

Gonzalez, Jospeh M. (2005). Sleeping bodies, jubilant souls: the fate of the dead in Sweden 1400-1700. Canadian Journal of History, 40(2), 199-227.

Hale, David. (1973). Analogy of the body politic. In P. P. Weiner (Ed.), Dictionary of the history of ideas (pp. 18-70). New York: Charles Scribner's.

Hale, John R. (1993). The civilisation of Europe in the Renaissance. London: Harper Collins. 
Corruption: Expanding the focus

Harding, Robert. (1981). Corruption and the moral boundaries of patronage in the Renaissance. In G. F. Lytle \& S. Orgel (Eds), Patronage in the Renaissance (pp. 47-64). Princeton: Princeton University Press.

Harrington, James. (1977 [1656]). The commonwealth of Oceana. Cambridge: Cambridge University Press.

Harvey, A. D. (1999). The body politic: anatomy of a metaphor. Contemporary Review, 275(1603), 85-93.

Hicks, Philip. (2005). The Roman matron in Britain: female political influence and the republican response, ca. 1750-1800. The Journal of Modern History, $77(1), 35-69$.

Hirschman, Albert O. (1977). The passions and the interests: political arguments for capitalism before its triumph. Princeton: Princeton University Press.

Hobbes, Thomas. (1996 [1651]). Leviathan. R. Tuck (Ed.). Cambridge: Cambridge University Press.

Hughes, Ann (Ed.). (1980). Seventeenth-century England: a changing culture. Volume I: primary sources. London: Ward Lock Educational.

International Monetary Fund. (1997). Good governance: the IMF's role. Washington, DC: International Monetary Fund.

Jardine, Lisa. (1996). Worldly goods: a new history of the Renaissance. London: Macmillan.

Jenner, Mark S. R. (2002). The roasting of the rump: scatology and the body politic in Restoration England. Past and Present, 177, 96-102.

John of Salisbury. (1909). Policratici (Clemens C. I. Webb, Trans., Vol. I). Oxford: The Clarendon Press.

John of Salisbury. (1990 [c. 1159]). Policraticus: of the frivolities of courtiers and the footprints of philosophers. Cambridge: Cambridge University Press.

Kantorowicz, Ernst H. (1957). The king's two bodies: a study in mediaeval political theology. Princeton: Princeton University Press.

Kaufman, Peter I. (2009). Augustine and corruption. History of Political Thought, $30(1), 46-59$.

King Charls his Speech made upon the Scaffold. (1649). Retrieved 9 July 2004 from <http://justus.anglican.org/resources/pc/charles/charlesl.html> 
Kinney, Arthur F. (Ed.). (1990). Elizabethan backgrounds: historical documents of the age of Elizabeth I. Hamden: Archon.

Knox, John. (1878 [1558]). The first blast of the trumpet against the monstrous regiment of women. London: Southgate.

McCall, Andrew. (1979). The medieval underworld. London: Book Club Associates.

McLaren, A.N. (1996). Delineating the Elizabethan body politic: Knox, Aylmer and the definition of counsel 1558-88. History of Political Thought, XVII(2), 224-252.

Machiavelli, Niccolò. (1906 [1532]). Florentine histories (N. H. Thomson, Trans., Vol. 1). London: Archibald Constable.

Machiavelli, Niccolò. (1965 [1521]). The art of war (E. Farneworth, Trans.). New York: Da Capo.

Machiavelli, Niccolò. (1996 [c. 1517]). Discourses on Livy (H. C. Mansfield \& N. Tarcov, Trans). Chicago: University of Chicago Press.

Mandeville, Bernard. (1970 [1724]). Fable of the bees and remarks. Philip Harth (Ed.). London: Penguin.

Mansfield, Harvey C. (1996). Introduction. In Niccolò Machiavelli, Discourses on Livy. Chicago: University of Chicago Press.

Marsilius of Padua. (2005 [1324]). The defender of the peace (Annabel Brett, Trans.). Cambridge: Cambridge University Press.

Nederman, Cary J. (1988). Nature, sin and the origins of society: the Ciceronian tradition in medieval political thought. Journal of the History of Ideas, 49(1), 3-26.

Nederman, Cary J. (2000a). Community and the rise of commercial society: political economy and political theory in Nicholas Oresme's De Moneta. History of Political Thought, XXI(1), 1-15.

Nederman, Cary J. (2000b). The expanding body politic: Christine de Pizan and the medieval roots of political economy. Paper presented at the Au Champ Des Escriptures: IIIe Colloque International sur Christine de Pizan, Paris.

Nederman, Cary J. (2003). Community and self-Interest: Marsiglio of Padua on civil life and private advantage. The Review of Politics, 65(4), 395-416.

Nederman, Cary J. (2004). Body politics: the diversification of organic metaphors in the later Middle Ages. Pensiero Politico Medievali, 2, 59-87. 
Corruption: Expanding the focus

Nicholls, Colin, Daniel, Tim, Polaine, Martin, \& Hatchard, John (Eds). (2006). Corruption and misuse of public office. Oxford: Oxford University Press.

Noonan, John Thomas. (1984). Bribes: the intellectual history of a moral idea. Berkeley: University of California Press.

Nye, Joseph S. (2002). Corruption and political development: a cost-benefit analysis. In Arnold J. Heidenheimer \& Michael Johnston (Eds), Political corruption: concepts and contexts (3rd edn, pp. 281-302). New Brunswick: Transaction Publishers.

Peck, Linda Levy. (1990). Court patronage and corruption in early Stuart England. Boston: Unwin Hyman.

Philp, Mark. (1997). Defining political corruption. Political Studies, 45, 436-62.

Pizan, Christine. (1994 [1404-07]). The book of the body politic. (K.L. Forhan. Trans. and ed.), Cambridge: Cambridge University Press.

Pocock, J. G. A. (1975). The Machiavellian moment: Florentine political thought and the Atlantic republican tradition. Princeton: Princeton University Press.

Ponet, John. (1556). A short treatise of politik power. London: British Library (W462573).

Rahe, Paul Anthony. (2009). Against throne and altar: Machiavelli and political theory under the English republic. Cambridge: Cambridge University Press.

Rose-Ackerman, Susan. (1999). Corruption and government: causes, consequences and reform. Cambridge and New York: Cambridge University Press.

Schama, Simon. (1987). The embarrassment of riches: an interpretation of Dutch culture in the golden age. London: Fontana.

Shah, Anwar. (2006). Corruption and decentralized public governance. Policy Research Working Paper WPS 3824 (pp. 1-28). Washington, DC: The World Bank.

Sidney, Algernon. (1990 [c. 1682]). Discourses concerning government. Indianapolis: Liberty Classics.

Sidney, Algernon. (1996 [c. 1665]). Court maxims. Hans W. Blom, Eco HaitsmaMulier and Ronald Janse (Eds). Cambridge: Cambridge University Press.

Saint Augustine. (1998 [413-26AD]). The city of God against the pagans (R. W. Dyson, Trans.). Cambridge: Cambridge University Press. 
Starkey, Thomas. (1973 [1540]). Exhortation to unitie and obedience. Amsterdam and New York: Theatrum Orbis Terrarum and Da Capo Press.

Swart, Koenraad W. (2002). The sale of public offices. In Arnold J. Heidenheimer \& Michael Johnston (Eds), Political corruption: concepts and contexts (3rd edn, pp. 95-106). New Brunswick: Transaction Publishers.

Tanner, J. R. (1951). Tudor constitutional documents AD 1485-1603 with an historical commentary (2nd edn). Cambridge: Cambridge University Press.

Temple, William. (1932 [1690]). Observations upon the united provinces of the Netherlands. Cambridge: Cambridge University Press.

Thomas, John Henry. (1986 [1836]). Systematic arrangement of Lord Coke's first institute of the laws of England (Vol. 2). Buffalo: William S. Hein.

Von Gierke, Otto. (1958 [1900]). Political theories of the Middle Age (F. W. Maitland, Trans.). Boston: Beacon Press.

W. S. (1954 [1581]). A discourse of the common weal of this realm of England. Elizabeth Lamond (Ed.). Cambridge: Cambridge University Press.

Waquet, Jean-Claude. (1991). Corruption: ethics and power in Florence, 1600 1770 (Linda McCall, Trans.). Cambridge: Polity.

Whelan, Frederick G. (2009). Enlightenment, political thought and non-Western societies. New York: Routledge.

Woodfine, Philip. (2004). The rhetoric and practice of corruption in Walpolean politics. In Emmanuel Kreike \& William Chester Jordan (Eds), Corrupt histories (pp. 167-96). New York: University of Rochester Press. 